\author{
ACTA MYCOLOGICA \\ Vol. 47 (1): 3-9 \\ 2012
}

\title{
Relationship between source of water, occurrence, and pathogenicity of Phytophthora plurivora
}

\author{
LESZEK B. ORLIKOWSKI, ALEKSANDRA TRZEWIK \\ MAGDALENA PTASZEK and TERESA ORLIKOWSKA \\ Research Institute of Horticulture \\ Konstytucji 3 Maja 1/3, PL-96-100 Skierniewice, leszek.orlikowski@inhort.pl
}

Orlikowski L. B., Trzewik A., Ptaszek M., Orlikowska T.: Relationship between source of water, occurrence, and pathogenicity of Phytophthora plurivora. Acta Mycol. 47 (1): 3-9, 2012.

Phytophthora plurivora was the most often detected species from water using rhododendron baits. The species was isolated from water of two rivers, Jasieniec and Korabiewka, a water pond and a drainage canal from March to November, 2008 (in Korabiewka river also in December). The highest population density of $P$. plurivora was observed in March and April in water pond and canal, and in May in both analysed rivers. In laboratory trials all tested isolates colonized rhododendron and poplar leaves. Isolates from drainage canal were the most pathogenic for rhododendron. Isolates detected in March from water pond and two rivers caused the quickest spread of necrosis on leaf blades. On poplar leaves the fastest development of necrotic spots was observed when isolates obtained in June and November were used for inoculation, while the isolate from September sample was less pathogenic.

Key words: soilborne pathogens, water sources, bait, detection, pathogenicity

\section{INTRODUCTION}

Phytophthora species are soilborne pathogens able to affect several hundred plant species worldwide. Currently about 160 species belong to this genus (Jung 2011 unpbl., pers. communic. on COST Meeting, Sękocin 2011). They occur on all continents except of Antarctica, causing several losses in forests and ornamental nurseries. Hong and Moorman (2005), detected 17 Phytophthora and 26 Pythium species, 27 fungi determined to the genus level, 8 bacteria species, 10 viruses and 13 species of parasitic nematodes from water used for plant sprinkling. Among them $P$. plurivora Jung \& Burgess is one of the most dangerous pathogen (Orlikowski et al. 2004, 2006; Orlikowski, Ptaszek 2010; Orlikowski et al. 2011a). The pathogen was described for the first time in 1927 by Sawada on Sekkan orange fruit as P. citricola 
Sawada. Many isolates described as $P$. citricola in the world collections differ from each other, so Jung and Burgess (2009), on the basis of molecular, morphological and physiological methods described new species named as $P$. plurivora in the $P$. citricola complex. Nowadays most of $P$. citricola isolates were renamed as $P$. plurivora and this species is one of the most often isolated from the $P$. citricola complex.

$P$. citricola is known in Poland as the main reason for ericaceous and coniferous ornamental plants dying as well as the cause of stem base rot of forest trees (Orlikowski et al. 1995; Orlikowski, Szkuta 2003a, b; Orlikowski et. al. 2004, 2006; Orlikowski, Ptaszek 2010; Orlikowski et al. 2011b). Among different sources of plant pathogens, including nursery seedlings, infested soil and transmission on machine parts, water in the opinion of Hong and Moorman (2005) is a primary if not the sole, source of inoculum for Phytophthora diseases of numerous nursery, fruit and vegetable crops. The aim of current studies was to estimate the occurrence of $P$. plurivora in different water sources in relation to sampling time, and pathogenicity of the species toward Rhododendron sp. and Populus alba L.

\section{MATERIAL AND METHODS}

Water sources. Studies were conducted in two rivers in Łódź and Warsaw districts (Jasieniec [RJ] and Korabiewka [RK]), in a water pond [S1] localized in ornamental nursery, from which the water is taken for plant sprinkling, and in a drainage canal [C1] to which surplus water from plant watering is running off. Jasieniec is swimming through small forests, fields, but also among horticulture farms growing ericaceous, deciduous and coniferous plants. Korabiewka is forest small river contaminated by plant pathogens during spring time and the local floods.

Isolation of Phytophthora species from water. Sampling of Phytophthora spp. was carried out during whole year, each month in 2008. For pathogen's isolation baiting technique described by Themann and Werres (1998) and Orlikowski (2006) was used. Twigs of Rhododendron cv. Nova Zembla were immersed in water for 4-7 days (depending on year season). Thereafter leaves were taken out from water, put in plastic bags and transported to the laboratory. Leaves were washed in tap and in distilled water and dabbed dry. On each leaf blade the number of necrotic spots was counted as a measure of Phytophthora infection density. In sterile laminar bench chosen leaves were sterilized over a burner flame and small fragments of Rhododendron sp. tissues were cut from individual necrotic spots and put onto PDA medium in Petri dishes (90 $\mathrm{mm}$ in diam.). Plates were incubated in the dark at $20^{\circ} \mathrm{C}$. Within the next 2 days colonies growing around plant tissues were transferred onto PDA slants. After a few days isolates were grouped on the basis of growth pattern and representative cultures were taken for further identification.

Identification of Phytophthora species. DNA was extracted from mycelium using the method described by Aljanabi and Martinez (1997), modified by Wiejacha et al. (2002). At a first step PCR with non-specific primers: RAPD and ISSR were used (Trzewik et al. 2006). Results were confirmed using PCR with species specific primers for P. citricola complex CITR1/CITR2 (Schubert et al. 1999). 
Pathogenicity of $\boldsymbol{P}$. plurivora. Trials were conducted in laboratory conditions using method described by Orlikowski and Szkuta (2001). Isolates of $P$. plurivora obtained from different water sources in subsequent months were used. Rhododendron and poplar leaf blades were washed under tap and distilled water, dabbed dry and put to plastic trays onto moist sterile blotting paper covered with plastic net. Three mm diameter discs, overgown by $P$. plurivora, taken from margins of 7-days old PDA cultures, were put in wounded central part of leaf blade. Clean PDA medium was used as the control. Trays were covered with foil and incubated in $22-24^{\circ} \mathrm{C}$. Within 7 days the diameter of necrosis was measured. Experimental design was completely randomized with 4 replications and 5 leaf blades in each replication. Duncan multiple range test was used for mean separation.

\section{RESULTS AND DISCUSSION}

Detection of Phytophthora plurivora from water. During one-year studies 384 leaf baits were analysed on the occurrence of $P$. plurivora in 4 sources of water (Tab. 1).The species was detected from drainage canal, water reservoir and 2 rivers from March to November, 2008 (in Korabiewka river also in December), except water pond in June and Jasieniec river in November. The highest number of this species isolates was noticed in March, April and May. Decrease of Phytophthora population from summer to autumn Themann et al. (2002) indicated on the presence of chemical compounds for Oomycetes in water, and mixture of Phytophthora contaminated pond water with fresh water from well. Orlikowski et al. (2007) provided that Phytophthora species were never isolated from a well.

The analysis of Phytophthora isolates number from water showed, that baiting time and place of baits holding were not correlated with the frequence of these pathogens group detection. The number of $P$. plurivora isolates obtained from a canal, water pond and Korabiewka river was similar and varied form 76 to 83 (Tab.

Table 1

Occurrence of Phytophthora plurivora in water from different sources in relation to detection time

\begin{tabular}{|c|c|c|c|c|c|c|c|c|}
\hline \multirow{2}{*}{$\begin{array}{c}\text { Sampling } \\
\text { time } \\
\text { (months) }\end{array}$} & \multicolumn{7}{|c|}{ Number Phytophthora isolates (a), including P. plurivora (b) } \\
\cline { 2 - 9 } & \multicolumn{2}{|c|}{ Drainage canal } & \multicolumn{2}{c|}{ Water pond } & \multicolumn{2}{c|}{ Jasieniec river } & \multicolumn{2}{c|}{ Korabiewka river } \\
\hline & $\mathrm{a}$ & $\mathrm{b}$ & $\mathrm{a}$ & $\mathrm{b}$ & $\mathrm{a}$ & $\mathrm{b}$ & $\mathrm{a}$ & $\mathrm{b}$ \\
\hline I & - & - & - & - & - & - & 4 & 4 \\
\hline II & - & - & 3 & 3 & - & - & - & - \\
\hline III & 35 & 28 & 33 & 20 & 13 & 9 & 6 & 6 \\
\hline IV & 31 & 27 & 27 & 25 & 11 & 9 & 2 & 1 \\
\hline V & 6 & 6 & 13 & 13 & 16 & 14 & 13 & 13 \\
\hline VI & 3 & 2 & 4 & 0 & 5 & 5 & 12 & 12 \\
\hline VII & 6 & 6 & 3 & 3 & 3 & 2 & 7 & 7 \\
\hline VIII & 2 & 1 & 5 & 3 & 11 & 11 & 8 & 8 \\
\hline IX & 5 & 3 & 5 & 4 & 11 & 5 & 9 & 9 \\
\hline X & 7 & 4 & 3 & 3 & 2 & 2 & 12 & 12 \\
\hline XI & 9 & 6 & 8 & 2 & - & 0 & 3 & 3 \\
\hline XII & - & - & - & - & - & 0 & 11 & 8 \\
\hline
\end{tabular}


1), while from Jasieniec river, only 57 cultures were detected. It was probably connected with the localization of this river further than other already mentioned river and plant species growing along it. Ghimire et al. (2009) claimed, that diversity and population density of Phytophthora spp. occuring in water depends on the range and number of cultivated plants and geographic localisation of nurseries. Our current studies affirm that thesis. Jasieniec is flowing throught horticulture area, but nurseries are placed about $200-1000 \mathrm{~m}$ from this river, so zoospores from affected plants are not transported to the water. The occurrence of $P$. plurivora in analysed water sources is probably connected with the presence of this species on deciduous, coniferous and ericaceous plants as well as on trees growing along river banks. The pathogen was probably introduced to water with parts of soil and substrata, fragments of diseased roots or infected leaves which could be a source of energy for Phytophthora. In river water zoospores released from zoosporangia are transported for a long distance (Miligroom, Peever 2003) and they could infect others, new host plants such as alder, poplar or willow growing along banks. In nurseries, propagules from diseased plants are washed off and transported with excess water and rain to water ponds and canals, usually situated in their lowest points. During hot summer, when plants are being watered few times per day, effluents in ponds are mixed with well water or river water before sprinkling and use for plant irrigation. Such situation cause the threat for the spread of Phytophthora zoospores on new host plants in nursery. Previous observation of Orlikowski (2006) indicated the spread of $P$. citricola propagules, mainly zoospores, together with effluent water used for sprinkling of Thuja occidentalis L. cv. fastigiata Jaeger, Buxus sempervirens L. and Rhododendron sp. Occurrence of tip blight of thuja and rhododendron and shoot and root rot of boxwood was observed to be preceded by drizzly weather and air humidity about $90 \%$ during at least 2 days. On thuja within 8 days disease symptoms spread from $7 \%$ (initial observation) to $40 \%$. On Rhododendron sp. during 2 months necrotic spots were observed on $13 \%$ of crop whereas on boxwood first yellowing was noticed in the middle of July and after 15 weeks the disease occured on $15 \%$ of plants.

P. citricola was detected from forest rivers and streams in north-east part of France (Hansen, Delatour 1999), from water-recycling irrigation system at a perennial container nursery in south-western Virginia (Bush et al. 2003) and also from reservoirs in German commercial hardy ornamental nurseries with water recirculation system (Themann et al. 2002). The species was commonly occuring plant pathogen accomodated to various enviromental conditions.

Rhododendron leaves were found to be effective baits for $P$. plurivora detection from all water sources, what is in agreement with study of Orlikowski et al. (2011b), who indicated that leaves of this plant are the most efficient bait for Phytophthora species detection. These authors showed that more than $70 \%$ of Phytophthora citricola isolates from different water sources were obtained using rhododendron leaf bait.

Colonisation of plant parts by $\boldsymbol{P}$. plurivora isolates from river. In the laboratory trials all tested isolates colonized rhododendron and poplar leaf blades (Figs 1, 2). In the trials with rhododendron the quickest spread of necrosis was observed when cultures from drainage canal were used. In the case of other water sources more pathogenic were isolates detected in March than in other months. The slowest rate of necrosis development was observed on rhododendron leaves inoculated with isolates from Jasieniec river detected in September (Fig. 1). In the studies with poplar 


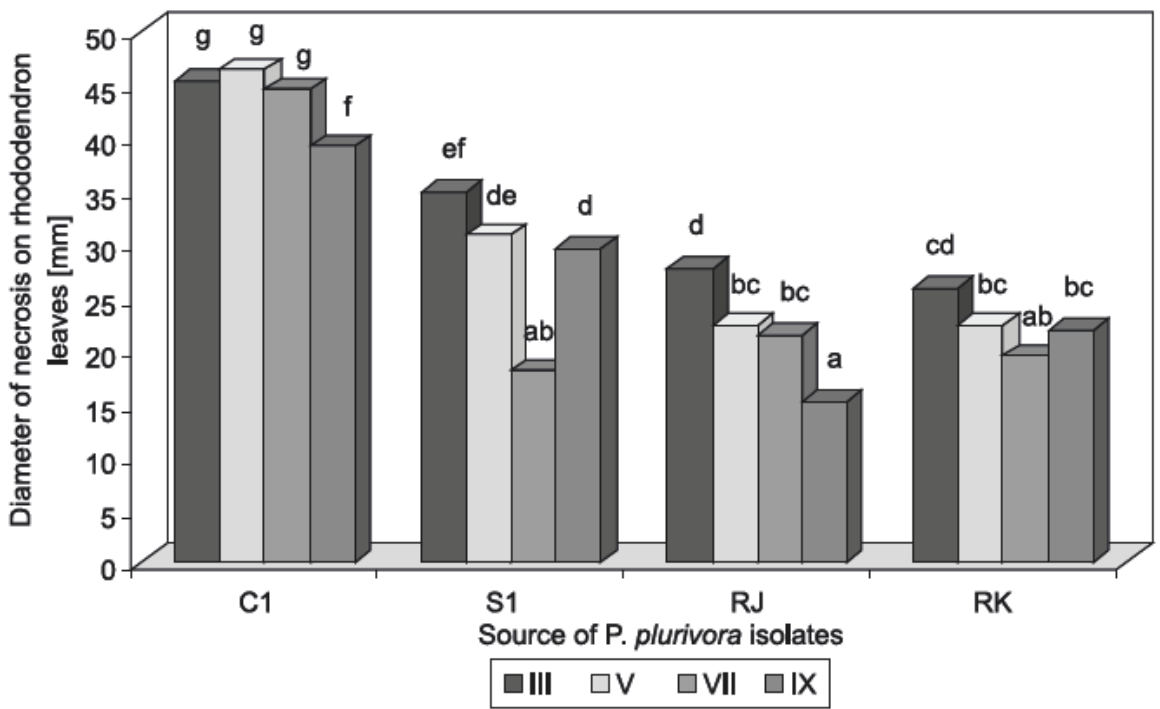

Note: means followed by the same letter (a-g) do not differ with $5 \%$ of significance acc. to Duncan's multiple range test

Fig. 1. Relationship between source of $P$. plurivora isolates, baiting time and colonization of rhododendron leaves.

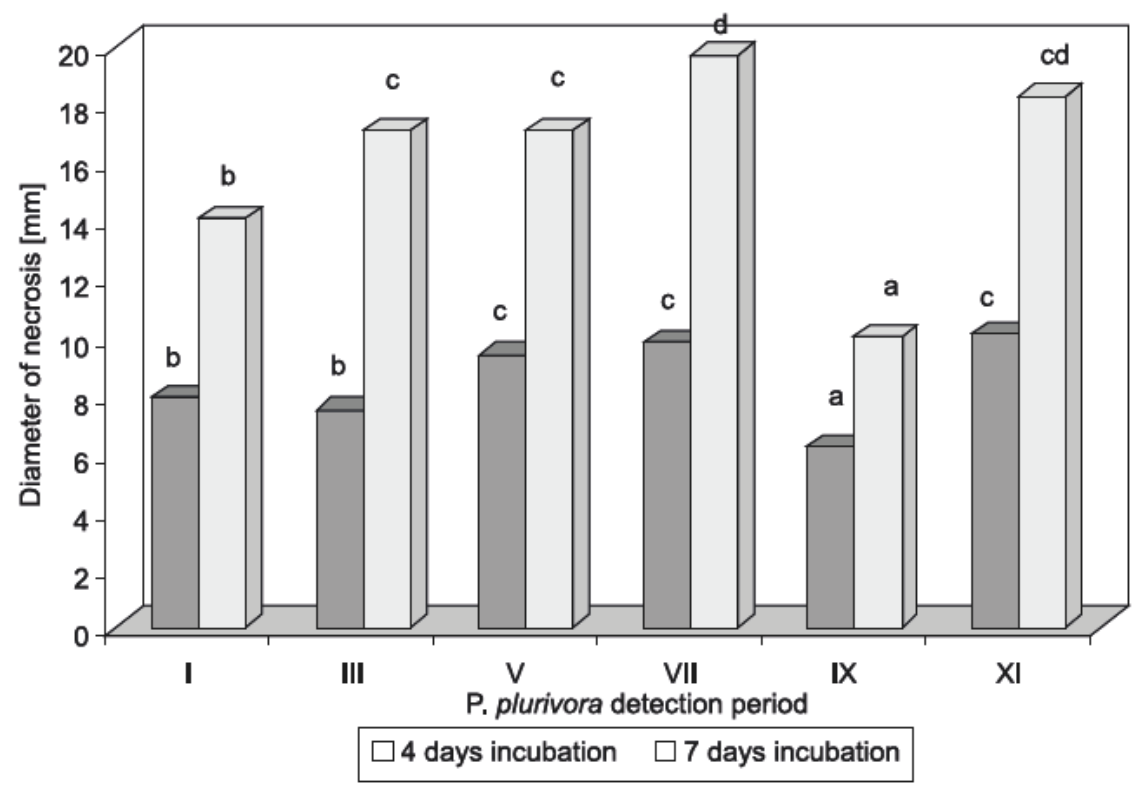

Note: means followed by the same letter (a-d) do not differ with $5 \%$ of significance acc. to Duncan's multiple range test

Fig. 2. Colonization of poplar leaves by $P$. plurivora isolates obtained from different months in 2008 from Korabiewka river. 
the quickest spread of necrotic spots was observed for cultures from July and November and the slowest for September isolate (Fig. 2).

Our results confirm earlier data on the occurrence and pathogenicity of $P$. plurivora. Orlikowski et al. (2010) showed significant variation in the necrosis development on inoculated alder leaves by $P$. plurivora from water obtained in different year periods. Cultures of $P$. plurivora isolated from the Ner river, flowing mainly throught Łódź district, in March, May and August colonized alder tissues quicker than an isolate from October. Isolates from water pond and canal obtained in March were more pathogenic for alder leaves than those from other months. Such relationships are probably connected with contamination of water with some chemicals which influenced on isolates pathogenicity (Themann et al. 2002). Orlikowski et al. (2010) showed also that the isolates of this species colonized rhododendron, poplar and willow tissues with the fastest spread of necrosis on rhododendron leaf blades as the most sensitive plant species for this pathogen. Moreover, among three Phytophthora species isolated from water in 2007, P. plurivora was the most pathogenic for birch leaves and stem fragments as well as for alder leaves (Orlikowski et al. 2008). Pathogenicity of that species toward different plants in relation to detection period will be evaluated in the nearest future.

Acknowledgments. Studies were supported by Ministry of Science and Higher Education $(475 / \mathrm{N}-\mathrm{COST} / 2009 / 0)$.

\section{REFERENCES}

Aljanabi S.M., Martinez I. 1997. Universal and rapid salt-extraction of high quality genomic DNA for PCR-based techniques. Nucl. Acids Res. 25: 4692-4693.

Bush E.A., Hong C.X., Stromberg E.L. 2003. Fluctuations of Phytophthora and Pythium spp. in components of recycling irrigation system. Plant Dis. 87: 1500-1506.

Ghimire S.R., Richardson P.A., Moorman G.W., Lea-Cox J.D., Ross D.S., Hong C.X. 2009. An in-situ baiting bioassay for detecting Phytophthora species in irrigation runoff containment basins. Plant Pathol. 58: 577-583.

Hansen E., Delatour C. 1999. Phytophthora species in oak forests of north-east France. Ann. For. Sci. 56: 539-547.

Hong C.X., Moorman G.W. 2005. Plant pathogens in irrigation water: challenges and opportunities. Crit. Rev. Plant Sci. 24: 189-208.

Jung T., Burgess T.I. 2009. Re-evaluation of Phytophthora citricola isolates from multiple woody hosts in Europe and North America reveals a new species Phytophthora plurivora sp. nov. Persoonia 22: 95-110.

Miligroom M.G., Peever T.L. 2003. Population biology of plant pathogens. Plant Dis. 87: 608-617.

Orlikowski L.B. 2006. Relationship between source of water used for plant sprinkling and occurrence of Phytophthora shoot rot and tip blight in container-ornamental nurseries. J. Plant Prot. Res. 46: 163-168.

Orlikowski L.B., Gabarkiewicz R., Skrzypczak C. 1995. Phytophthora species in Polish ornamental nurseries. Isolation and identification of Phytophthora species. Phytopathol. Pol. 9: 73-79.

Orlikowski L.B., Oszako T., Duda B., Szkuta G. 2004. Occurrence of Phytophthora citricola on ash (Fraxinus excelsior) in forest nurseries. Leśne Prace Badawcze 4: 129-136.

Orlikowski L.B., Oszako T., Szkuta G. 2006. First record of Phytophthora spp. associated with the decline of European beech stand in south-west Poland. Phytopathol. Pol. 42: 37-46.

Orlikowski L.B., Ptaszek M. 2010. Phytophthora species as the causal agents of thuja (Thuja spp.) decay in Polish hardy ornamental nursery stocks. Sylwan 154 (4): 242-248. 
Orlikowski L.B., Ptaszek M., Rodziewicz A., Nechwatal J., Thinggaard K., Jung T. 2011a. Phytophthora root and collar rot of mature Fraxinus excelsior in forest stands in Poland and Denmark. For. Path. 41: 510-519.

Orlikowski L.B., Ptaszek M., Trzewik A., Orlikowska T. 2008. Relationship between source of water, surveying time and occurrence of Phytophthora spp. Progr. Plant Prot./Post. Ochr. Roślin 48 (1): $246-251$.

Orlikowski L.B., Ptaszek M., Trzewik A., Orlikowska T. 2011b. Usefulness of plant leaf baits for detection of Phytophthora spp. from water. Sylwan 155 (7): 493-499.

Orlikowski L.B., Ptaszek M., Trzewik A., Orlikowska T., Wojtkowska M. 2010. Occurrence of Phytophthora spp. in water and pathogenicity of chosen isolates of Phytophthora citricola for plants. Zesz. Probl. Post. Nauk Rol. 554: 159-164.

Orlikowski L.B., Szkuta G. 2001. Dieback of Pieris japonica caused by Phytophthora citrophthora. Acta Mycol. 36: 251-256.

Orlikowski L.B., Szkuta G. 2003a. First notice of Phytophthora tip blight on Picea omorika and Thuja occidentalis in Poland. Phytopathol. Pol. 28:63-67.

Orlikowski L.B., Szkuta G. 2003b. Phytophthora citricola on Rhododendron sp. in Polish nurseries. J. Plant Prot. Res. 43: 21-24.

Orlikowski L.B., Trzewik A., Orlikowska T. 2007. Water as potential source of Phytophthora spp. in ornamental nurseries. Materials from conference „Problems and prospects for nursery production of ornamental plants", Skierniewice: 189-193.

Schubert R., Bahnweg G., Nechwatal J., Jung T., Cooke D.E.L., Duncan J.M., Müller-Starck G., Langebartels C., Sandermann H. Jr., Oßwald W.F. 1999. Detection and quantification of Phytophthora species which are associated with root-rot disease in European deciduous forests by species-specific polymerase chain reaction. Eur. J. For. Pathol. 29: 169-188.

Themann K., Werres S. 1998. Verwendung von Rhododendronblättern zum Nachweis von PhytophthoraArten in Wurzel- und Bodenproben. Nachr. Dtsch. Pflanzenschutz. 50: 37-45.

Themann K., Werres S., Lüttmann R., Diener H.A. 2002. Observations of Phytophthora spp. in water recirculation systems in commercial hardy ornamental nursery stock. Eur. J. Plant Pathol. 108: 337343.

Trzewik A., Wiejacha K., Orlikowski L.B., Szkuta G., Orlikowska T. 2006. The identification of five Phytophthora species on the basis of DNA markers obtained via the PCR technique with non-specific primers. Phytopathol. Pol. 41: 27-37.

Wiejacha K., Szkuta G., Orlikowska T. 2002. Optimization of DNA isolation procedure as the first step in identification of Phytophthora spp. Bull. Pol. Acad. Sci. 50, Biol. Sci. 3: 165-171.

\section{Współzależność pomiędzy źródłem wody a występowaniem i patogenicznością Phytophthora plurivora}

\section{Streszczenie}

Phytophthora plurivora izolowano od marca do listopada 2008 roku z dwóch rzek Jasieniec (RJ) i Korabiewka (RK), zbiornika wodnego (S1) zlokalizowanego na terenie szkółki oraz kanału (C1) odprowadzającego nadmiar wody z kontenerowni. Największą liczbę izolatów uzyskano w marcu i kwietniu z kanału i zbiornika, a w maju z obu rzek. W warunkach laboratoryjnych wszystkie testowane kultury kolonizowały blaszki liściowe różanecznika i topoli. Izolaty z kanału okazały się najbardziej patogenicznymi dla różanecznika. Kultury z marca, uzyskane z trzech źródeł wody (S1, RJ, RK), powodowały szybszy rozwój nekrozy niż pochodzące z prób z innych miesięcy. Najszybsze tempo zasiedlania tkanek liści topoli obserwowano po inokulacji kulturami uzyskanymi z prób z lipca i listopada, a najwolniejsze w przypadku izolatu z września. 